\title{
Review on the Effects of Climate Change Variability on Horticultural Productivity
}

\author{
Fekadu Hailu Hirpo* and Marshet Nigatu Gebeyehu \\ Natural Resource Management Specialized in Forest and Nature Management, Jimma University, Ethiopia
}

Submission: February 11, 2019; Published: March 06, 2019

*Corresponding author: Fekadu Hailu Hirpo, Natural Resource Management Specialized in Forest and Nature Management, Jimma University, Jimma, Ethiopia

\section{Abstract}

Globally climate change variability and its effects are the highest concern of mankind in 21st century. Due to terminal heat stress and deprived soil water availability most physiological disorder responses to climate changes like reduced growing period, causing distinctive reduction in production of fruits and vegetables; will leave negative influence on growth and development of horticultural crops. The productivity and quality besides aggravate the environmental stresses such as increasing temperature, reduced irrigation water availability; flooding and salinity are effects on horticultural crops by climate change variability. Due to irregularity of climate change variability the commercial varieties of fruits, vegetables and flowers will perform poorly in an unpredictable manner. Due to melting of ice cap in the Himalayan regions particularly marketable production of horticultural plants that grown under open field conditions will be severely affected. Some horticultural crops like Spongy tissue of mango, fruit cracking of litchi, flower and fruit abscission in solanaceous fruit vegetables will be more pronounced in physiological disorder and declined in yields of several horticultural crops due to high temperature and air pollutions. By minimizing the effect of climate changes and greater use of greenhouse technology are some of the solutions to sustain the productivity and modification of present horticultural practices. Developing horticultural crops tolerant to high temperature, resistant to pests and diseases, short duration and producing good yields under stress conditions will be the main strategies to meets these challenges.

Keywords: Fruit crops; Physiological disorder; Vegetable crops; Crops yields

\section{Introduction}

Globally, with diverse soils and climate containing several agro-ecological regions provides sufficient opportunity to grow many varieties of horticultural crops. Which form a significant part of total agricultural productions in the world comprising of fruits, vegetables, flowers and other ornamental plants, medicinal and aromatic plants, spices, condiments, plantation crops and mushrooms [1]. However, the horticultural productions and productivity are extremely affected by Climate change variability. Rainfall patterns and unpredictable high temperature are the major parameters of climate change that has far reaching implications on agriculture in general and horticulture in particular [1].

Agriculture and horticulture are the most susceptible to climate change and global warming [2]. This is because the amounts of photosynthesis and accumulation and weather condition such as temperature, sunshine duration and rain fall has a huge influence on those photosynthesis and accumulation of most crops yields. Droughts, floods and colds are the most climate extremes that have significant effects on agricultural productions over the world [2]. Many studies indicated that climate change has a significance effects on horticultural productions; especially rising temperature can affect the breaking dormancy of many perennials crops like pip fruit, kiwifruit and blackcurrants.

About the global and regional impacts of projected climate change on agriculture, water resources, natural ecosystems and food nutritional security as the reports of Fourth Intergovernmental Panel on Climate Change [3]. Impacts of climate changes like droughts, hailstorms, heavy rains, floods, frosts, cyclones and others abiotic stresses every year, different regions and provinces experience as disasters. Agricultural productivity through high and low temperature regimes and increased rainfall variability are threatened by resulting shifting weather patterns in changing climate $[4,5]$.

Climate change variability affectation is the major challenges influencing the performance of agriculture including annual and perennial horticultural crops. Due to terminal heat stress and decreased water availability the productions of fruits and vegetables are reduced; that caused by short growing period, 
which will have negative impacts on growth and development particularly. Due to rainfall variability and decrease in numbers of rainy days, rain-fed agriculture will be mainly impacted [6]. Horticultural productions systems have thrown up greater uncertainties and threats; result in price hike of fruits and vegetable crops, further imposing limitations due to climate change and climate variability. To achieve the targeted production and productivity; growing demands in the environment of declining land, water and risk of climate change, which needs climate smart horticulture interventions are highly located $[4,7]$.

By achieving in the challenges and consequences of climate changes like changes in seasonal patterns, excessive rains, floods, hailstorms, frosts, high temperature and droughts leading to extremities; horticulture production will be improved. Due to shortening of growing periods, decreases in water accessibility and poor expression resulted in yield reductions. Physiological responses of the crops, effects on growth and development, quality and productivity will be required to measures the impacts of climate change on horticultural crops. This will be used in order to prepare the horticultural sector to face the imminent challenges of climate changes. The higher respiration rate, vary photosynthesis rate and separating of photosynthesis to economic parts, alter the phenology, shorten the crop duration, days to flowering and fruiting, hasten fruit maturity, ripening and senescence may be occurred due to rise in temperature. Rising in temperature may be not being consistently disseminated between day and night and among different seasons [8]. Even if moderate warming in tropical regions, it may result to disproportionate declines in crops yields.

Crops yields may improve as a result of a small rise in temperatures in high latitudes. Whereas, in lower latitudes especially in developing countries, temperatures are already closer to or beyond thresholds and further warming would decrease rather than increase productivity. The influence of climate change is expected to differ with location and types of crops in horticultural sector. Even in high yield and high technology in agricultural areas, climate change variability is one of the most important factors influencing year to year on crops productions [9]. Global issues like increases in temperature, changes in rainfall patterns, sea level rises, saltwater intrusions, generation of floods and droughts are resulted by climate change variability [10]. Generally, as a result of climate change variability, different horticultural crops production and productivity will be decreased. This affects the society in most part of our world in terms of economy and food security. Therefore, the objective of this paper is to review the impacts of climate change variability on different horticultural production and productivity.

\section{Method}

The method used to write the review on the effects of climate change variability on horticultural production and productivity through collecting, different journals from different sources starting from 2005 up to now. Lastly the collected articles were organized and summarized accordingly.

\section{Implications of climate change on horticultural productivity}

Erratic rainfall patterns and unpredictable high temperatures are the two major constraints of climate changes that have far reaching effects on agriculture in general and horticulture in particular; are spells will consequently decrease crop productivity [1]. Latitudinal and altitudinal changes in ecological and agro-economic zones, land degradation, extreme geophysical events, reduced water availability, rise in sea level and salinization are other factors that have significant effects on horticultural productions and productivity.

Climate change variability will have many impacts on horticultural plants and a few examples are given below.

a) Due to rise in temperature, the production timing will be change. Increasing in temperature, photoperiods may not show much difference; resulted photosensitive crops will mature faster.

b) The temperate crops will be affected by the winter regime and reducing the chilling duration in temperate regions.

c) Due to extreme temperature, Pollinations will be affected badly because of floral abortions; flower and fruit drop will be occurred frequently.

d) The requirements of heat unit and the requirements of annual irrigation will increase, to

achieve in much lesser time.

e) Due to extreme temperatures, tuber initiation process in potato, quality in tomatoes and pollination in many crops will be reduced. In regarding to crucifers, it may lead to bolting; anthocyanin production can be affected in apples and capsicum. Tip burn and blossom end rot will be soak common phenomenon in tomatoes.

f) In inland water tables producing more salinity; because, coastal regions can expect much faster percolation of sea water.

\section{Effects on fruit crops}

As a result of increases in atmospheric temperature and changes of rainfall patterns due to climate changes; banana cultivation may suffer from high temperature, soil moisture stress and flooding/ water logging. Similarly, increases sunburn and cracking in apples, apricot and cherries and rise in temperature at maturity will lead to fruits cracking and burning in litchi due to high temperature and moisture stress [11]. The reduction in yields of several horticultural crops and increases the intensity of certain physiological disorders such as black tip 
of mango which is induced by coal fume gases, sculpture dioxide, ethylene, carbon monoxide and fluoride may be occurs due to air pollutions in the atmosphere.

Rising in temperature, lesser days helping as the chilling period have starting to disturb the mountain agricultural production systems and eventually the food security of the peoples due to the changes in climate in the form of erratic precipitations. This affects the chilling requirements of pome and stone fruits because the dormancy breaking will be earlier. The considerable damages on many fruit crops as the result of extreme weather events of hot and cold wave conditions have been reported [12]. Increase in temperature resulted to have influences on the flowering phenology of perennial crops like mango and guava, which has vegetative bias.

\section{Effects on vegetable crops}

India and china are the largest producer of vegetables in the world and accounts for about $15 \%$ of the world's production of vegetables in India [1]. The current production total area under vegetable cultivation is around 6.2 million hectares which is about $3 \%$ of the total area under cultivations in the country. Vegetable plants may respond to avoid more stresses through morphological or biochemical mechanisms [13]. The stress response of plants more complex or influence the degree of impacts in climate changes due to environmental interactions. Lists of some abiotic stress vegetables have been presented in Table 1.

Table 1: List of some abiotic stresses' vegetable crops.

\begin{tabular}{|c|c|c|}
\hline No. & Tolerant & Crops \\
\hline 1 & Drought tolerant & $\begin{array}{c}\text { Chili, Melons, Tomato, } \\
\text { Onion }\end{array}$ \\
\hline 2 & Heat tolerant & $\begin{array}{c}\text { Peas, Tomato, Beans, } \\
\text { Capsicum }\end{array}$ \\
\hline 3 & Salinity tolerant & Melons, Peas, Onion \\
\hline 4 & $\begin{array}{c}\text { Flooding/ excess } \\
\text { moisture tolerant }\end{array}$ & Tomato, Onion, Chili \\
\hline
\end{tabular}

Source: Rai and Yadav, (2005).

However, many significant losses in tomato productivity as a result of reducing fruits set, and smaller and lower quality fruits due to high temperatures. The symptoms causing fruits set failure due to high temperatures in tomato's productions such as bud drop, abnormal flower development, poor pollen production, dehiscence and capability, ovule abortion and poor viability, reduced carbohydrate accessibility and other reproductive abnormalities [14]. In pepper, high post-pollination temperatures inhibited fruits set, suggesting that fertilization is sensitive to high temperature stresses but, high temperature exposure at the pre-anthesis stage did not affects pistil or stamen viability. The result in losses of turgor, growth reduction, wilting, leaf curling and epinasty, leaf abscission, decreases photosynthesis, respiratory changes, loss of cellular integrity, tissue necrosis, and potentially death of the plants due to plants are very sensitive to salt stresses. Similarly, flooding and genetic difference with respect to this character is inadequate; most of the vegetable crops are highly sensitive.

Plants accumulate endogenous ethylene that causes damages to the plants of flooded crops particularly in tomato. Rising in temperatures; rapid wilting and death of tomato plants is regularly observed resulting a short period of flooding at high temperatures increases the severity of flooding symptoms. The vegetable crops will be affected more when they grow close to the densely populated areas due to the risk of air pollution. A current study showed that in case of Brassica oleracia, Lactuca sativa and Raphanus sativus; the ambient air pollution significantly reduced the yield more than 50 percent. Most vegetable crops like tomato, water melon, potato, squash, soyabeans, cantaloupe, peas, carrot, beet, turnip, etc. are more susceptible to air pollutions damages, and the yields of those vegetable can be reduced by 5-15 percent when day-to-day ozone concentrations reach to greater than $50 \mathrm{ppb}$ [15].

\section{Effects on plantation crops}

Climate change variability related events like repeated droughts and cyclones badly

affects the coconut yields (like droughts in Tamil Nadu and Karnataka, cyclone) [16]. Consecutive droughts reduced the coconut production and productivity losses were the tune of about 3500nuts/hectare/year in India. Other natural calamities like cyclone have impacted the crops production and productivity apart from drought. Increasing $\mathrm{CO} 2$ led to higher biomass production in coconut, areca nut and cocoa but, a slight decline will be occurred in biomass production was apparent at elevated air temperature. Those three crops responded differentially under elevated air temperature. For example: - areca nut and cocoa, net photosynthesis rate has increased under elevated air temperature but reduced that of coconut.

Many findings showed that the rain fed cashew crop is extremely sensitive to changes in

climate and weather vagaries; mainly during reproductive phase particularly studies led on "Impact of climate change in cashew" at Directorate of Cashew Research, Putter, in India improved this idea. Cashew needs moderately dry atmosphere and mild winter $\left(15-20^{\circ} \mathrm{C}\right)$ joined with moderate precipitation during night for abundant flowering [12]. The drying of flowers and resulting in yield reductions due to low relative humidity $(<20 \%)$ and high temperature $\left(>34.4^{\circ} \mathrm{C}\right)$ during afternoon period. Changes such as paucity and poor supply of rain, rise in temperature and violent winds, will be reduced the productivity of cashew trees due to abortion or drying of the flowers, fallen of the leaves and the immature fruits and in severe situations it may lead to unproductiveness [17]. The occurrence of pests and diseases due to unseasonal rains and heavy precipitation during flowering and fruiting period will be serious and caused in reduction yields up to $50 \%$ to $65 \%$. 


\section{Effects on spice crops}

In the world generally, due to increase in maximum and minimum day temperature and decreasing the annual rainfall the productivity exhibited declining trends in most of the black pepper growing areas particularly in India. Many studies show that significant changes in weather components and have had major impacts on the production of spices crops like small cardamom, seed spices and black pepper [18]. Similarly, other's finding shows that the area under pepper farming has come down by $24 \%$ in nine years while production has declined nearly half during the period due to diminishing productivity and increasing production costs. In Karnataka Pepper is seen to be less monsoon sensitive and grown mainly in the irrigated coffee plantations [19]. Also, the impacts of climate change on medicinal and aromatic plants have been reviewed in detail by [20].

In some parts of the world especially in Iran and Spain have most famous for its saffron; water shortages are straining the crops and also Kashmir's prized saffron crops have suffered $40 \%$ drop in productions. To save their unusual and labor-intensive crops, certain of the saffron farmers who traditionally relied on rainwater are now considering at irrigation measures. Some Spices seeds are commonly winter season crops and grown in arid and semi-arid requiring certain periods of low temperature for optimum vegetative growth. Due to collective effects of chilling and frost injury; heavy losses have been observed. Particularly in spices crops like Cumin, coriander, nigella and ajowan are the crops which are very sensitive to frost and also causing serious losses in yields almost reaches up to zero. Even if frost has an important role in growth stage of fennel and fenugreek, it affects mostly. To identify the source of resistance besides low temperature damages in accessible germplasm seeds of spices crops; so far, no efforts have been made.

\section{Effects on flower crops}

The flowering of many ornamental plants such as Rhododendron, Orchid, Tulipa, Alstromerea, Magnolia, Saussurea, Impatiens, Narcissus etc. will be reduced the chilling requirement due to the melting of ice cap in the Himalayan regions. Some of them will be threatened while others will fail to bloom or flower with less abundance. With high humidity the Cauliflower performs well in the temperature range of 15$25^{\circ} \mathrm{C}$ and some varieties have adapted to temperatures over $30^{\circ} \mathrm{C}$ while, most varieties are sensitive to higher temperatures and delayed curd initiation is observed [21]. Plant species particularly flowering plants will be required high humidity and water under difficult conditions for survival. As a result of drought or excessive rains, floods and seasonal variations Plains of India will have alike kind of difficulties and will be affected.

Primary to poor flowering, improper floral growth and color of commercial production of flowers particularly grown under open field conditions will be severely affected. One example of short-day plant is Chrysanthemum; because of this flowering around the year in open field situation is not possible. In Jasmine low temperatures shut down flowering $\left(<19^{\circ} \mathrm{C}\right)$ and lead to decrease in flower size. In tropical orchids wherever, temperatures below $15^{\circ} \mathrm{C}$ flowers do not open up fully. However, in tropical orchids high temperature leads to flower bud drop and unmarketable spikes when temperature remains $>35^{\circ} \mathrm{C}$.

\section{Conclusion}

In summary, the anthropogenic global climate changes due to the extreme releases of $\mathrm{CO} 2$ into the atmosphere are strong. There are many thinkable impacts of climate changes on horticultural crops; the effects of changes on water use of horticultural crops are mainly significant. Horticultural crops especially vegetables are one of the good sources of vitamins and minerals and play a significant role in ensuring food and nutritional security. They are extremely perishable and very vulnerable to unpredictable climatic changes. Climate change variability has an adverse impact on productivity and quality, moreover, aggravates the environmental stress on horticultural crops. Environmental stresses such as increasing temperature, reduced irrigation water availability, rise in $\mathrm{CO} 2$ concentration, flooding and salinity are supposed to be the major limiting factors in enhancing horticultural production and productivity.

\section{Recommendation}

Horticulturists will have to play an important role in the climate change situation and appropriate strategies have to be predicted for saving horticultural crops. Adopt conservation agriculture, using renewable energy, forest and water conservation, reforestation, afforestation, wetland protection etc. are the most effective way to sustain the productivity of horticulture. Modification of present horticultural practices and greater use of greenhouse technology are some of the solutions to reduce the effects of climate change. Improvement of new cultivars of horticultural crops tolerant to high temperature, resistant to pests and diseases, short duration and producing good yields under stress conditions; as well as implementation of hi -tech horticulture and careful management of land use resources will be the main strategies to meet the challenges of productivity losses.

\section{Acknowledgment}

We would like to express our special thanks to Mr. Dessalegn Obsi for his valuable help to the finalization of this article review.

\section{References}

1. Datta S (2013) Impact of climate change in indian horticulture - a review. International Journal of Science, Environment and Technology 2(4): 661-671.

2. Choul Kim (2013) Impacts of climate change on New Zealand horticulture and the effectiveness of government policy at production level: a case study. 
3. IPCC (2007) Climate change: Fourth assessment report of the Intergovernmental panel on Climate change (IPCC), WMO, UNEP.

4. Malhotra SK, Srivastva AK (2014) Climate smart horticulture for addressing food, Nutritional security and climate challenges. Shodh Chintan- Scientifc articles, by Srivastava AK ASM Foundation, New Delhi, India, pp. 83-97.

5. Eduardo Somarriba, Rolando Cerda, Luis Orozcoa, Miguel Cifuentesa, Hector Davila, et al. (2013) Carbon stocks and cocoa yields in agroforestry systems of Central America. Agriculture Ecosystems and Environment 173: 46-57.

6. Venkateswarlu B, Shanker AK (2012) Dry land agriculture: bringing resilience to crop production under changing climate. Crop Stress and its Management: Perspectives and strategies. Springer, Netherlands, pp. 19-44.

7. Malhotra SK (2015) Hydroponic in horticulture, an overview. Soilless Gardening India Magazine 11: 6-8.

8. Srinivasa RaoNK, Laxman RH, Bhatt RM (2010) Impacts of climate change on vegetable crops. In: Singh HP, Singh JP, Lal SS (Eds.), Challenges of Climate Change in Indian Horticulture, Westville Publications House, New Delhi, India, pp. 113123.

9. Kang Y, Khan S, Xiaoyi Ma (2009) Climate change impacts on crop yield, crop water productivity and food security - A review. Progress in Natural Science 19(12): 1665-1674.

10. Bates BC, Kundzewicz ZW, Wu S, Palutikof JP (2008) Climate change and water. IPCC Technical Paper VI, Geneva, p. 210.

11. Kumar R, Kumar KK (2007) Managing physiological disorders in litchi. Indian Horticulture 52(1): 22-24

12. Malhotra SK (2017) Horticultural crops and climate change. Indian Journal of Agricultural Sciences 87(1): 12-22.
13. Capiati DA, País SM, Téllez-Iñón MT (2006) Wounding increases salt tolerance in tomato Plants; evidence on the participation of calmodulin like activities in cross tolerance signaling. J Exp Bot 57(10): 2391-2400.

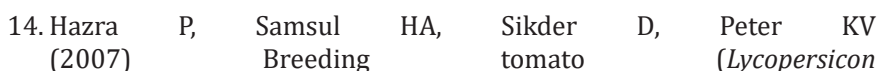
Esculentum Mill) resistant to high temperature stress. International Journal of Plant breeding 1(1): 31-40.

15. Raj Narayan (2009) Air pollution a threat in vegetable productions. In: Sulladmath UV, Swamy KRM (Eds.), International Conference on Horticulture. Horticulture for Livelihood Security and Economic Growth, pp.158-159.

16. Laxman RH, Shivasham Bora KS, Srinivasa Rao NK (2010) An assessment of potential impacts of climate change on fruit crops. Singh HP, Singh JP, Lal SS (Eds.), Challenges of Climate Change in Indian Horticulture, Westville Publishing, New Delhi, India, pp. 23-30.

17. Balogoun I, Ahoton EL, Saidou A, Bello OD, Ezin V (2016) Effect of climatic factors on Cashew (Anacardium occidentale L.) productivity in Benin (West Africa). Journal of Earth Science and Climatic Change 7: 329 .

18. Murugan M, Shetty PK, Ravi R, Anandhi A, RajKumar AJ (2012) Climate change and crop yields in the Indian Cardamom Hills, 1978-2007 CE. Climatic Change 110 (3-4): 737-753.

19. Ravi J (2012) Effect of climate change on crops: Declining pepper production.

20. Das Manish, Jain Vanita, Malhotra SK (2016) Impact of climate change on medicinal \& aromatic plants: A review. Indian Journal of Agricultural Sciences 86 (11): 1375-1382.

21. Singh HP (2010) Impacts of climate change on horticultural crops In: Singh HP, Singh JP, Lal SS (Eds.), Challenges of Climate Changes in Indian Horticulture, Westville Publishing House, New Delhi, India, pp. 1-8.

\section{Your next submission with Juniper Publishers will reach you the below assets}

- Quality Editorial service

- Swift Peer Review

- Reprints availability

- E-prints Service

- Manuscript Podcast for convenient understanding

- Global attainment for your research

- Manuscript accessibility in different formats

( Pdf, E-pub, Full Text, Audio)

- Unceasing customer service

Track the below URL for one-step submission https://juniperpublishers.com/online-submission.php 